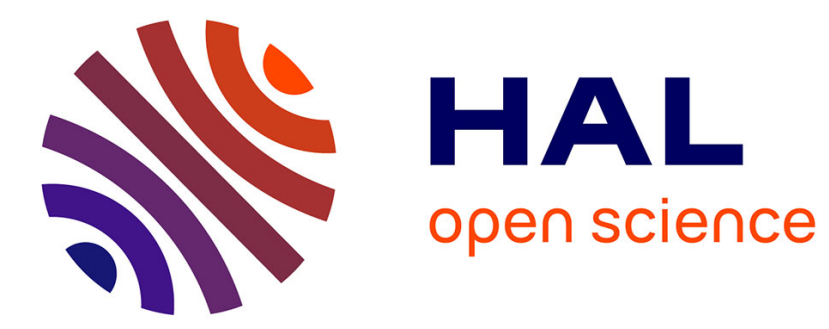

\title{
Role of TRPV1 receptors in descending modulation of pain
}

\author{
Enza Palazzo, Francesco Rossi, Sabatino Maione
}

\section{To cite this version:}

Enza Palazzo, Francesco Rossi, Sabatino Maione. Role of TRPV1 receptors in descending modulation of pain. Molecular and Cellular Endocrinology, 2008, 286 (1-2), 10.1016/j.mce.2008.01.013 . hal00531985

\section{HAL Id: hal-00531985 \\ https://hal.science/hal-00531985}

Submitted on 4 Nov 2010

HAL is a multi-disciplinary open access archive for the deposit and dissemination of scientific research documents, whether they are published or not. The documents may come from teaching and research institutions in France or abroad, or from public or private research centers.
L'archive ouverte pluridisciplinaire HAL, est destinée au dépôt et à la diffusion de documents scientifiques de niveau recherche, publiés ou non, émanant des établissements d'enseignement et de recherche français ou étrangers, des laboratoires publics ou privés. 


\section{Accepted Manuscript}

Title: Role of TRPV1 receptors in descending modulation of pain

Authors: Enza Palazzo, Francesco Rossi, Sabatino Maione

PII: $\quad$ S0303-7207(08)00017-8

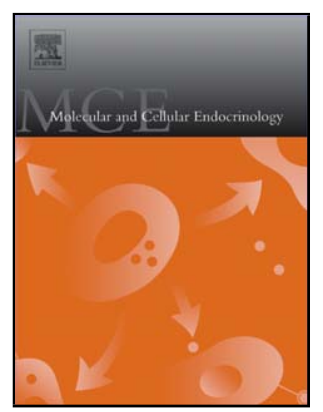

DOI: $\quad$ doi:10.1016/j.mce.2008.01.013

Reference: $\quad$ MCE 6795

To appear in: $\quad$ Molecular and Cellular Endocrinology

Received date: $\quad 17-1-2008$

Accepted date: $\quad 18-1-2008$

Please cite this article as: Palazzo, E., Rossi, F., Maione, S., Role of TRPV1 receptors in descending modulation of pain, Molecular and Cellular Endocrinology (2007), doi:10.1016/j.mce.2008.01.013

This is a PDF file of an unedited manuscript that has been accepted for publication. As a service to our customers we are providing this early version of the manuscript. The manuscript will undergo copyediting, typesetting, and review of the resulting proof before it is published in its final form. Please note that during the production process errors may be discovered which could affect the content, and all legal disclaimers that apply to the journal pertain. 


\title{
Role of TRPV1 receptors in descending modulation of pain
}

\author{
Enza Palazzo*, Francesco Rossi, Sabatino Maione*
}

Department of Experimental Medicine- Section of Pharmacology "L. Donatelli"- Faculty of Medicine and Surgery - Second University of Naples, Via Costantinopoli, 1680138 Naples - Italy.

*Corresponding author: Enza Palazzo, Department of Experimental Medicine, Section of Pharmacology, The Second University of Naples, via Costantinopoli 16, 80138, Naples, Italy

Tel 0039-081-5667531; Fax 0039-081-5667503; email: enza.palazzo@unina2.it

*Corresponding author: Sabatino Maione, Department of Experimental Medicine, Section of Pharmacology, The Second University of Naples, via Costantinopoli 16, 80138, Naples, Italy

Tel 0039-081-5667650; Fax 0039-081-5667503; email: sabatino.maione@unina2.it 


\begin{abstract}
Transient receptor potential vanilloid type 1 (TRPV1) receptor is a ligand-gated non selective cation channel activated by heat $\left(>43^{\circ}\right)$, low $\mathrm{pH}$ and endogenous lipid molecules such as anandamide, $\mathrm{N}$ arachydonoyl-dopamine, N-acyl-dopamines and products of lipoxygenases (12-and 15-(S)-HPETE) termed endovanilloids. Apart from peripheral primary afferent neurons and dorsal root ganglia, TRPV1 receptor is expressed throughout the brain. Recent evidence show that TRPV1 receptor stimulation by endocannabinoids or by capsaicin within the periaqueductal grey (PAG) leads to analgesia and this effect is associated with glutamate increase and the activation of OFF cell population in the rostral ventromedial medulla (RVM). Activation of the antinociceptive descending pathway via TPRV1 receptor stimulation in the PAG may be a novel strategy for producing analgesia. This review will summarize the more recent insights into the role of TRPV1 receptor within the antinociceptive descending pathway and its possible exploitation as a target for novel pain-killer agents.
\end{abstract}

Keywords: Endocannabinoids; Transient receptor potential vanilloid type 1, Periaqueductal grey, Rostral ventromedial medulla, ON and OFF cells; Pain. 


\section{Introduction}

Periaqueductal gray (PAG)-rostral ventromedial medulla (RVM)-dorsal horn circuitry is the bestcharacterized nociceptive modulatory system through which pain is endogenously inhibited. In particular, PAG plays a key role in the descending modulation of nociception (Behbehani 1995; Fields 2000), although this region has limited direct projections to the spinal cord (Sandkuhler and Gebhart 1984), uses the RVM, as an intermediate relay station (Basbaum and Fields 1984; Fields et al. 1995), which in turn projects directly to the spinal cord dorsal horn.

Transient receptor vanilloid type-1 (TRPV1), formerly known as the vanilloid receptor (VR1), is a ligand-gated non selective cation channel that is considered to be an important pain integrator. It can be activated not only by exogenous agents such as capsaicin (the pungent ingredient of hot pepper) or resiniferatoxin (isolated from cactus-like plant) but also by many endogenous stimuli, including heat $\left(>43^{\circ}\right)$, low $\mathrm{pH}$ and endovanilloids (Caterina et al., 1997; Chuang et al., 2001; De Petrocellis et al., 2004; Ferreira et al., 2004; Premkumar and Ahern, 2000; Tominaga et al., 1998; Szallasi and Blumberg, 1999; Starowicz et al., 2007a). The role of TRPV1 receptor in pain-related behaviour has been definitely demonstrated using TRPV1 receptor gene knockout mice, which showed impairment in detecting thermal painful stimuli without altered mechanical noxious responses (Caterina et al., 2000). Most research on the TRPV1 receptor's role in pain facilitation and pain transmission has been carried out at peripheral and spinal level (Nagy et al., 2004; Sasamura and Kuraishi, 1999). Nevertheless, data on the role of the TRPV1 receptor in the supraspinal control of pain is still scant, despite the fact that increasing evidence confirms the expression of TRPV1 receptors throughout the brain (Cristino et al., 2006; Liapi and Wood 2005; Maione et al., 2006; Mezey et al., 2000; Roberts et al., 2004; Sanchez et al., 2001; Toth et al., 2005). Increasing evidence demonstrates the presence of TRPV1 receptors throughout the periaqueductal gray (PAG) (Cristino et al., 2006; Maione et al., 2007; McGaraughty et al., 2003; Starowicz et al., 2007). Stimulation of TRPV1 receptors in the PAG has been proven to inhibit pain by either acting on the downstream rostral ventromedial (RVM) neurons that mediate analgesia or by desensitizing the activity of other neurons involved in inducing hyperalgesia (McGaraughty et al., 2003; Palazzo et al., 2002; Starowicz et al., 2007b). In this review we highlight studies that report supraspinal TRPV1 receptor involvement in pain modulation with particular emphasis on the descending antinociceptive pathway areas such as the PAG and RVM. 


\section{Endogenous ligands of TRPV1 receptors}

Endogenous ligands using TRPV1 receptors for- inter and intracellular signaling have been termed endovannilloids (Di Marzo et al., 2001; Starowicz et al., 2007a). First endovanilloid to be identified has been anandamide (Ross et al., 2003; Smart et al., 2000; Zygmunt et al., 1999). Later on the chemical similarity between anandamide and capsaicin, and in particular between $\mathrm{N}$-acylvanyllamide ligands and $\mathrm{AM404}$, the inhibitor of anandamide membrane transporter, led to multiplicity of studies testing the activity of endocannabinoids on TRPV1 receptors and vice versa. $\mathrm{N}$-acyldopamine (Huang et al., 2002; Chu et al., 2003) and Narachidonoy-dopamine (NADA) (Hwang et al., 2000) were found to activate TRPVI receptors as well as several products of lypoxygenases, among these 12-(S)-hydroperxyeicosatetraenoic acid [12-(S)HPETE], 15-(S)-hydroperoxyeicosatetraenoic acid [15-(S)HPETE] and leukotriene $\mathrm{B}_{4}\left(\mathrm{LTB}_{4}\right)$ showed the highest efficacy (Hwang et al., 2000).

\section{Expression of TRPV1 in the brain}

In the brain TRPV1 receptors have been identified in various regions known for their role in pain transmission or modulation (Mezey et al., 2000; Roberts et al., 2004; Szabo et al., 2002). These regions include RVM, PAG, amygdala, solitary tract nucleus, somatosensory cortex, anterior cingulated cortex and insula (Millan, 1999; 2002). The TRPV1 receptor is localized in neuron cell bodies and dendrites, astrocytes and perivascular structures within the brain. (Liapi and Wood, 2005; Mezey et al., 2000; Roberts et al., 2004; Sasamura et al., 1998). At subcellular level TRPV1 receptors are mainly expressed on postsynaptic spines (Toth et al., 2005). Capsaicin evokes glutamate release from slices of hypothalamus and lumbar dorsal horn, but not cerebellum. Such capsaicin action has shown to be $\mathrm{Ca}^{2+}$ dependent and inhibited by the TRPV1 receptor antagonist, capsazepine, thus suggesting that TRPV1 receptor may be expressed on glutamatergic neurons in the hypothalamus (Sasamura et al., 1998)

\section{The role of brain TRPV1 receptors in pain.}

Early work by Bodnar et al. $(1982 ; 1983)$ demonstrated that intracerebroventricular (ICV) capsaicin injection decreased nociceptive threshold and reduced morphine- and stress-induced analgesia. ICV administration of capsazepine or ruthenium red (both TRPV1 receptor antagonists) attenuated nocifensive behavior induced by an intradermal injection of capsaicin or formalin in mice (Santos and Calixto, 1997). Furthermore, nociceptive thresholds were increased by the ICV infusion of two novel TRPV1 receptor antagonists, A-425619 and A-784168. A-425619 dose-dependently delayed the tail flick response to noxious thermal stimulation (McGaraughty, unpublished observation), while A-784168 reduced CFA-induced thermal hyperalgesia and the hind limb weight-bearing difference in a model of osteoarthritic pain. The locus coeruleous (LC) is activated by painful 
stimuli and its stimulation produces antinociception. Systemic capsaicin increased LC firing activity even after sensory nerve fibre destruction, confirming a central effect of capsaicin (Hajos et al., 1986; 1987). In accordance with this evidence, TRPV1 receptor activation with capsaicin increased glutamatergic miniature excitatory postsynaptic currents in LC (Marinelli et al., 2002). TRPV1 receptor stimulation by capsaicin application into the ventral tegmental area enhanced dopaminergic output to the nucleus accumbens, following peripheral noxious stimulation, suggesting a novel role for TRPV1 channels in the mesencephalon (Marinelli et al., 2005).

\section{The role of TRPV1 receptors in periaqueductal grey}

Capsaicin (6 nmol/rat) injection into the dorsolateral (DL) PAG increased the latency of nociceptive responses, showing that stimulation of TRPV1 receptor within the descending antinociceptive pathway elicits analgesia. This effect requires glutamate release and subsequent activation of group I metabotropic glutamate (mGlu) and N-methyl-D-aspartate (NMDA) receptors. Indeed, riluzole, a voltage-dependent $\mathrm{Na}^{+}$channel blocker which inhibits the release of glutamate, mGlu subtypes I and $5\left(\mathrm{mGlu}_{1}\right.$ and $\left.\mathrm{mGlu}_{5}\right)$ and NMDA receptor antagonists blocked the analgesic effect of capsaicin. These data support the idea that intra-PAG capsaicin may generate analgesia by increasing the release of glutamate which activates the descending antinociceptive pathway via postsynaptic mGlu m $_{1 / 5}$ and NMDA receptors (Palazzo et al., 2002). McGaraughty et al., (2003) reported that capsaicin (10 nmol/rat) injected into the DL PAG decreases the latency of nociceptive behavioural responses, and showed that this compound induced hyperalgesia followed by analgesia; the latter possibly due to TRPV1 receptor desensitisation. Different concentrations of capsaicin used could be responsible of the different observed effect, due to the fact that extensive TRPV1 receptor stimulation may lead to desensitization. Recently, Maione et al., (2006) reported that the raising of the endocannabinoid level by URB597, an inhibitor of fatty acid amide hydrolase (FAAH), the enzyme which catalyses anandamide hydrolysis, resulted in differening dosedependent effects on pain responses. Hyperalgesia or analgesia have been observed depending on the recruitment of cannabinoid type 1 (CB1) or TRPV1 receptors by the increased endocannabinoid level (Fig.1). The hyperalgesia was proposed to be due to 2-arachidonoylglycerol (2-AG) increase and subsequent $\mathrm{CB} 1$ receptor stimulation which leads to inhibition of the antinociceptive PAGRVM descending pathway. Higher doses of URB597 caused rapid analgesia blocked by the TRPV1 receptor antagonist, capsazepine, thus being due to TRPV1 receptor stimulation. Therefore, endocannabinoids within the PAG affect the pain descending pathway by acting on either CB1 or TRPV1 receptor in a way that leads to facilitatory or inhibitory output to the RVM (Fig.1). Consistent with this finding, Maione et al. (2006) found that some neurons within the PAG coexpressed TRPV1 and CB1 receptors. A recent study has shown that the intra-ventrolateral (VL) 
PAG microinjection of capsaicin increased the latency of the nociceptive reaction (Starowicz et al., 2007b) according to what has been observed previously into the DL subregion of PAG (Palazzo et al., 2002). Conversely, the selective TRPV1 receptor antagonist 5'-iodo-resiniferatoxin (I-RTX) facilitates nociceptive responses and, at a per se inactive dose, abolishes capsaicin-mediated antinociception, hence suggesting that the effect of capsaicin was mediated by TRPV1 receptors. The antinociceptive effect of intra-VL PAG capsaicin was accompanied by an increase in glutamate release in RVM microdialysates, which was again blocked by a per se inactive dose of I-RTX. The TRPV1 receptor antagonist instead lowered the release of glutamate, thus suggesting that VL PAG TRPV1 receptors tonically stimulate glutamatergic output to the RVM, and concomitantly inhibit nociception. Only a slight increased dialysate GABA concentration was simultaneously observed. IRTX provoked a significant decrease in glutamate release and a very small, albeit significant, decrease of GABA. I-RTX at lower dose, which did not change the release of glutamate and GABA, antagonized the effect induced by capsaicin on extracellular glutamate release (Starowicz et al., 2007 b).

\section{TRPV1 positive neurons in the PAG}

A high density of TRPV1 receptor positive profiles with strong immunoreactivity (ir) was observed within the VL sub-region of the PAG. In the VL PAG, TRPV1 receptor was mostly found in cell bodies. In the PAG a high density of vesicular glutamate transporter 1 (VGLUT1)-ir on nerve terminals surrounding TRPV1 positive cells may indicate glutamatergic input on TRPV1-ir cell. In VL PAG many fibers were also vesicular GABA transporter (VGAT) positive, and VGAT-ir was observed around TRPV1 positive cells demonstrating that TRPV1-ir neurons could also receive GABAergic inputs (Starowicz et al., 2007b).

\section{Periaqueductal grey TRPV1 receptor- induced analgesia requires RVM neuron recruitment.}

Three different pain responding neuron types are found in the RVM (Fields et al. 1991). Cells of one class, "neutral cells", show no modification in spontaneous activity associated with nociceptive stimulation, whereas the other two classes of cells; "ON-cells" and "OFF-cells", play specific roles in nociceptive modulation. ON-cells show a burst of activity immediately prior to withdrawal reflexes while OFF-cells are inhibited. These cells respond in the opposite way to pharmacological stimulation with opioid receptor agonists: systemic or local injections of opioid receptor agonists sufficient to inhibit nociceptive reflexes inhibit ON-cell and increase OFF-cell activities (Fields et al. 1983; Heinricher and Tortorici 1994). These neurons in the RVM respond to capsaicin administration into the PAG (McGaraughty et al., 2003; Maione et al., 2006). The biphasic effect of intra-DL PAG microinjection of capsaicin correlates well with previous activation, followed by a 
decrease in the tail flick related ON-cell burst of activity. Moreover, during the later analgesic phase OFF-cell spontaneous firing increased (McGaraughty et al., 2003). The involvement of RVM ONand OFF-neurons in pain responses induced by intra-VL PAG microinjection of URB597 has been investigated by Maione et al., (2006). URB597 induced an immediate stimulatory effect on the OFF cell and an inhibitory action on the $\mathrm{ON}$ cells. These effects are consistent with behavioral analgesia Both effects were erased by capsazepine, which would suggest that TRPV1-receptor mediated analgesia that follows FAAH inhibition involves the activation of VL PAG neurons, which in turn stimulate RVM OFF cells and inhibit ON cells.

A recent paper by Starowicz et al. (2007b) has shown that intra VL PAG capsaicin at a dose of 6 $\mathrm{nmol} / \mathrm{rat}$ caused a decrease in the firing activity of the ON cells, and a very rapid increase in the firing activity of the OFF cells. Conversely, intra-VL PAG I-RTX increased the firing activity of ON cells and decreased the firing activity of the OFF cells. The effects of capsaicin were prevented by pre-treatment with I-RTX, at a dose which did not significantly change the RVM ON and OFF cell ongoing activities per se. Intra-VL PAG capsaicin also decreased tail flick-induced ON cell peak firing and delayed the onset of OFF cell pause. I-RTX at a higher dose increased the duration of the OFF cell pause and shortened its onset (Starowicz et al., 2007b).

\section{TRPV1 positive neurons in the RVM}

Expression of TRPV1 receptor in the RVM was mostly found in the cell bodies. In the RVM VGAT staining profile was similar to that observed in VL PAG, with TRPV1 receptor labeled cells being surrounded by VGAT-positive nerve terminals. VGLUT1 in RVM did not label only nerve fibers and terminals, but also several RVM cell bodies. Double immunofluorescence has identified several TRPV1/VGLUT1 positive cells and an intense co-expression in neurons of RVM. Moreover double TRPV1/ $\mu$ opioid receptor immunoreactivity colocalized in a vast majority of cell bodies of RVM neurons. These immunohistochemical data support the hypothesis that the increase/decrease in glutamate release observed in the RVM following intra-VL PAG injection of capsaicin/I-RTX correlated well with the activation/inhibition of RVM OFF neurons by the activation/inhibition of TRPV1-expressing glutamatergic neurons in this area.

\section{Summary}

The role of supraspinal TRPV1 receptors in pain control is still scant, though encouraging. TRPV1 receptor stimulation within the PAG with a direct agonist, such as capsaicin, or an indirect agonist such as URB597, which increases anandamide content by blocking its hydrolysis, leads to analgesia. This effect is associated with increased glutamate release and activation of group I mGlu and NMDA receptors and with activation downstream of RVM OFF neurons. Since, TRPV1 receptor blockade by I-RTX reduces glutamate release and leads to hyperalgesia, it would appear 
that within the PAG-RVM axis endogenous compounds capable of activating TRPV1 channels, termed "endovanilloids/endocannabinoids" tonically control nociception. One such compound might be anandamide, as suggested by our previous finding of TRPV1 receptors-mediated antinociception following intra-VL PAG injection of a selective inhibitor of anandamide enzymatic hydrolysis. Immunohistochemical data strongly support the hypothesis that the activation/inhibition of TRPV1 receptor-expressing glutamatergic neurons following intra-PAG injection of capsaicin/IRTX leads to an increase/decrease in glutamate release and behavioral analgesia/hyperalgesia. As well as the PAG-RVM antinociceptive axis, other regions of the brain known to influence descending pain modulation, such as the amygdala, thalamus and LC show TRPV1 receptor localization, although the exact contribution of these receptors, if any, has yet to be determined. Further studies to clarify the role of TRPV1 receptor within the brain, and in particular, within the antinociceptive descending pathway are still necessary. However, the possibility of exploiting TRPV1 receptor-mediated activation of the antinociceptive pain pathway has relevant perspective in the development of new analgesic agents hopefully suitable for some type of intractable pain. 


\section{References}

Basbaum, A.I., Fields, H.L., 1984. Endogenous pain control systems: brainstem spinal pathways and endorphin circuitry. Annu Rev Neurosci 7, 309-338.

Behbehani, M.M., 1995. Functional characteristics of the midbrain periaqueductal gray. Prog Neurobiol 46, 575-605.

Bodnar, R.J., Kirchgessner, A., Nilaver, G., Mulhern, J., Zimmerman, E.A., 1982. Intraventricular capsaicin: alterations in analgesic responsivity without depletion of substance $\mathrm{P}$. Neuroscience 7, 631-638.

Bodnar, R.J., Simone, D.A., Kordower, J.H., Kirchgessner, A.L., Nilaver, G., 1983. Capsaicin treatment and stress-induced analgesia. Pharmacol. Biochem. Behav. 18, 65-71.

Caterina, M..J., Schumacher, M.A., Tominaga, M., Rosen, T.A., Levine, J.D., Julius, D., 1997. The capsaicin receptor: a heat-activated ion channel in the pain pathway. Nature $389,816-824$.

Caterina, M.J., Leffler, A., Malmberg, A.B., Martin, W.J., Trafton, J., Petersen-Zeitz, K.R., Koltzenburg, M., Basbaum, A.I., Julius, D., 2000. Impaired nociception and pain sensation in mice lacking the capsaicin receptor. Science 288, 306-313.

Chuang, H.H., Prescott, E.D., Kong, H., Shields, S., Jordt, S.E., Basbaum, A.I., Chao, M.V., Julius, D., 2001. Bradykinin and nerve growth factor release the capsaicin receptor from PtdIns(4,5)P2-mediated inhibition. Nature 411, 957-962.

Cristino, L., de Petrocellis, L., Pryce, G., Baker, D., Guglielmotti, V., Di Marzo, V., 2006. Immunohistochemical localization of cannabinoid type 1 and vanilloid transient receptor potential vanilloid type 1 receptors in the mouse brain. Neuroscience 139, 1405-1415.

De Petrocellis, L., Cascio, M.G., Di Marzo, V., 2004. The endocannabinoid system: a general view and latest additions. Br. J. Pharmacol. 141, 765-74. 
V., Ferreira, J., da Silva, G.L., Calixto, J.B., 2004. Contribution of vanilloid receptors to the overt nociception induced by B2 kinin receptor activation in mice. Br. J. Pharmacol. 141, 787794.

Fields, H.L., 2000. Pain modulation: expectation, opioid analgesia and virtual pain. Prog. Brain. Res. 122, 245-253.

Fields, H.L., Bry, J., Hentall, I., Zorman, G., 1983. The activity of neurons in the rostral medulla of the rat during withdrawal from noxious heart. J. Neurosci. 3, 2545-2552.

Fields, H.L., Heinricher, M.M., Mason, P., 1991. .Neurotransmitters in nociceptive modulatory circuits. Ann. Rev. Neurosci. 14, 219-245.

Fields, H.L., Malick, A., Burstein, R., 1995. Dorsal horn projection targets of ON and OFF cells in the rostral ventromedial medulla. J Neurophysiol. 74, 1742-1759.

Hajós, M., Engberg, G., Elam, M., 1986. Reduced responsiveness of locus coeruleus neurons to cutaneous thermal stimuli in capsaicin-treated rats. Neurosci. Lett. 70, 382-387.

Hajós, M., Jancsó, G., Engberg, G., 1987. Capsaicin-induced excitation of locus coeruleus neurons. Acta Physiol. Scand. 129, 415-420.

Heinricher, M.M., Tortorici, V., 1994. Interference with GABA transmission in the rostral ventromedial medulla: disinhibition of off-cells as a central mechanism in nociceptive modulation. Neuroscience 63, 533-546.

Huang, S.M., Bisogno, T., Trevisani, M., Al-Hayani, A., De Petrocellis, L., Fezza, F., Tognetto, M., Petros, T.J., Krey, J. F., Chu, C.J., Miller, J.D., Davies, S.N., Geppetti, P., Walker, J.M., Di Marzo, V., 2002. An endogenous capsaicin-like substance with high potency at recombinant and native vanilloid VR1 receptors. Proc. Natl. Acad. Sci. USA 99, 8400-8405.

Hwang, S.W., Chom, H., Kwak, J., Lee, S.Y., Kang, C.J., Jung, J., Cho, S., Min, K.H., Suh, Y.G., Kim, D., Oh, U., 2000. Direct activation of capsaicin receptors by products of 


\section{lipoxygenases: endogenous capsaicin-like substances. Proc. Natl. Acad. Sci. USA 97, 6155-} 6160.

Liapi, A., Wood, J.N., 2005. Extensive co-localization and heteromultimer formation of the vanilloid receptor-like protein TRPV2 and the capsaicin receptor TRPV1 in the adult rat cerebral cortex. Eur. J. Neurosci. 22, 825-834.

Maione, S., Bisogno, T., de Novellis, V., Palazzo, E., Cristino, L., Valenti, M., Petrosino, S., Guglielmotti, V., Rossi, F., Di Marzo, V., 2006. Elevation of endocannabinoid levels in the ventrolateral periaqueductal grey through inhibition of fatty acid amide hydrolase affects descending nociceptive pathways via both cannabinoid receptor type 1 and transient receptor potential vanilloid type-1 receptors. J. Pharmacol. Exp. Ther. 316, 969-982.

Maione, S., De Petrocellis, L., de Novellis, V., Moriello, A.S., Petrosino, S., Palazzo, E., Rossi F., Woodward, D.F., Di Marzo, V., 2007. Analgesic actions of N-arachidonoyl-serotonin, a fatty acid amide hydrolase inhibitor with antagonistic activity at vanilloid TRPV1 receptors. Br. J. Pharmacol. 150, 766-781.

Marinelli, S., Pascucci, T., Bernardi, G., Puglisi-Allegra, S., Mercuri, N.B., 2005. Activation of TRPV1 in the VTA excites dopaminergic neurons and increases chemical- and noxious-induced dopamine release in the nucleus accumbens. Neuropsychopharmacology 30, 864-870.

Marinelli, S., Vaughan, C.W., Christie, M.J., Connor, M., 2002. Capsaicin activation of glutamatergic synaptic transmission in the rat locus coeruleus in vitro. J Physiol. 543, 531-540.

McGaraughty, S., Chu, K.L., Bitner, R.S., Martino, B., El Kouhen, R., Han, P., Nikkel, A.L., Burgard, E.C., Faltynek, C.R., Jarvis, M.F., 2003. Capsaicin infused into the PAG affects rat tail flick responses to noxious heat and alters neuronal firing in the RVM. J. Neurophysiol. 90, $2702-2710$

Mezey, E., Toth, Z.E., Cortright, D.N., Arzubi, M.K., Krause, J.E., Elde, R., Guo, A., Blumberg, P.M., Szallasi, A., 2000. Distribution of mRNA for vanilloid receptor subtype 1 (VR1), and VR1-like immunoreactivity, in the central nervous system of the rat and human. Proc. Natl. Acad. Sci. USA 97, 3655-3660. 
Millan, M.J., 1999. The induction of pain: an integrative review. Prog. Neurobiol. 57, 1-164.

Millan, M.J., 2002. Descending control of pain. Prog. Neurobiol. 66, 355-474.

Nagy, I., Sántha, P., Jancsó, G., Urbán, L., 2004. The role of the vanilloid (capsaicin) receptor (TRPV1) in physiology and pathology. Eur. J. Pharmacol. 500, 351-369.

Palazzo, E., de Novellis, V., Marabese, I., Cuomo, D., Rossi, F., Berrino, L., Rossi, F., Maione, S., 2002. Interaction between vanilloid and glutamate receptors in the central modulation of nociception. Eur. J. Pharmacol. 439, 69-75.

Premkumar, L.S., Ahern, G.P., 2000. Induction of vanilloid receptor channel activity by protein kinase C. Nature 408, 985-990.

Roberts, J.C., Davis, J.B., Benham, C.D., 2004. [3H]Resiniferatoxin autoradiography in the CNS of wild-type and TRPV1 null mice defines TRPV1 (VR-1) protein distribution. Brain Res. 995, 176-183.

Ross, A.R., 2003. Anadamide and vanilloid TRPV1 receptors. Br. J. Pharmacol. 140, 790801.

Sanchez, J.F., Krause, J.E., Cortright, D.N., 2001. The distribution and regulation of vanilloid receptor VR1 and VR1 5' splice variant RNA expression in rat. Neuroscience 107, 373-381.

Sandkuhler J, Gebhart GF (1984) Relative contributions of the nucleus raphe magnus and adjacent medullary reticular formation to the inhibition by stimulation in the periaqueductal grey of a spinal nociceptive reflex in the pentobarbital-anaesthetized rat. Brain Res 305: 77-87.

Santos, A.R., Calixto, J.B., 1997. Ruthenium red and capsazepine antinociceptive effect in formalin and capsaicin models of pain in mice. Neurosci Lett. 10, 235: 73-76.

Sasamura, T., Kuraishi, Y., 1999. Peripheral and central actions of capsaicin and VR1 receptor. Jpn. J. Pharmacol. 80, 275-280. 
Sasamura, T., Sasaki, M., Tohda, C., Kuraishi, Y., 1998. Existence of capsaicin-sensitive glutamatergic terminals in rat hypothalamus. Neuroreport 22, 2045-2048.

Smart, D., Gunthorpe, M.J., Jerman, J.C., Nasir, S., Gray, J., Muir, A.I, Chambers, J.K., Randall, A.D., Davis, J.B. The endogenous ipid anandamide is a full agonist at the human vanilloid receptor (hVR1). Br. J. Pharmacol. 129, 227-230.

Starowicz, K., Maione, S., Cristino, L., Palazzo, E., Marabese, I., Rossi, F.sca, de Novellis, V., Di Marzo, V., 2007a. Tonic endovanilloid facilitation of glutamate release in brainstem descending antinociceptive pathways. J. Neurosci., 27: 13739-49.

Starowicz K., Nigam S., Di Marzo V., 2007b. Biochemistry and pharmacology of endovanilloids. Pharmacol. Ther., 114: 13-33.

Szabo, T., Biro, T., Gonzalez, A.F., Palkovits, M., Blumberg, P.M., 2002. Pharmacological characterization of vanilloid receptor located in the brain. Brain Res. Mol. Brain Res. 98, 51-57.

Szallasi, A., Blumberg, P.M.., 1999. Vanilloid (Capsaicin) receptors and mechanisms. Pharmacol. Rev. 51, 159-212.

Tominaga, M., Caterina, M.J., Malmberg, A.B., Rosen, T.A., Gilbert, H., Skinner, K., Raumann, B.E., Szallasi, A., Blumberg, P.M., 1999. Vanilloid (Capsaicin) receptors and mechanisms. Pharmacol. Rev. 51, 159-212.

Toth, A., Boczan, J., Kedei, N., Lizanecz, E., Bagi, Z., Papp, Z., Edes, I., Csiba, L., Blumberg, P.M., 2005. Expression and distribution of vanilloid receptor 1 (TRPV1) in the adult rat brain. Brain Res. Mol. Brain Res. 135, 162-168.

Zygmunt, P.M., Petersson, J., Andersson D.A., Chuang, H., Sørgård, M., Di Marzo, V., Julius, D., Högestätt, E.D., 1999. Vanilloid receptors on sensory nerves mediate the vasodilator action of anandamide. Nature 400, 452-457. 


\section{Legend}

Fig. 1

Periaqueductal grey neuron population includes inhibitory (GABAergic, blue) and excitatory (glutammatergic, green) neurons. Activation of excitatory neuron stimulates descending antinociceptive pathway and produces analgesia, conversely, stimulation of GABAergic neurons or interneurons leads to hyperalgesia. Analgesia may be also the consequence of inhibition of GABAergic neurons and dishinibition of antinociceptive descending pathway. Stimulation of TRPV1 receptors (red circles) by endocannabinoids or capsaicin leads to analgesia, via stimulation of downstream RVM OFF neurons (yellow) or inhibition of $\mathrm{ON}$ neurons (red). This last effect is not direct and requires the activation of GABAergic interneuron. Stimulation of CB1 receptors (blu squares) by endocannabinoids may lead to analgesia or hyperalgesia depending on the recruitment of CB1 receptors on GABAergic or glutammatergic neurons, respectively. 


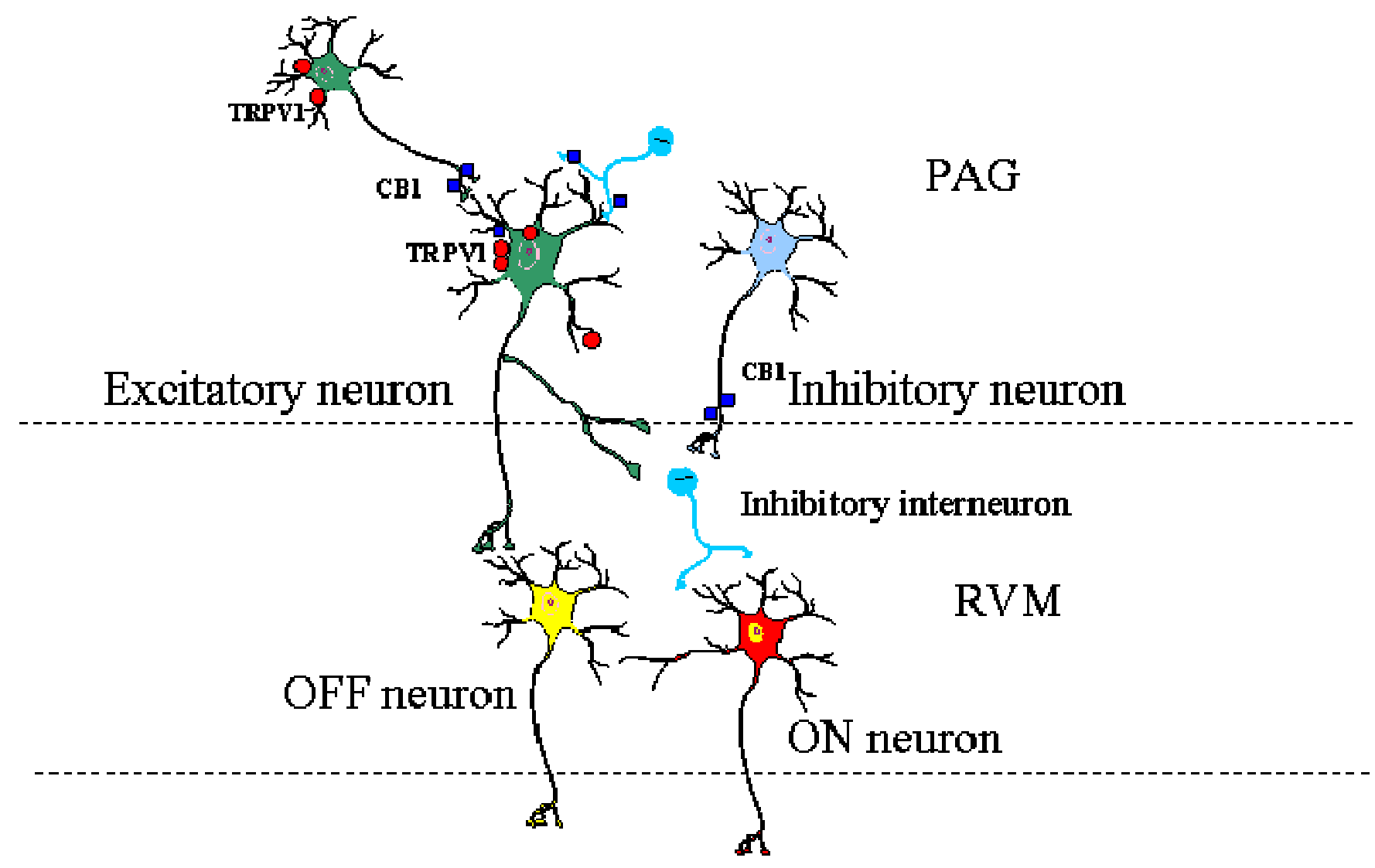

TO

DORSAL HORN 